\title{
<研究論文 >
}

\section{静的曲げモーメントを受ける同種材料段付き重ね合わせ 接着継手の三次元有限要素応力解析と強度推定}

\author{
市川 幸平 ${ }^{*}$ - 永井 利正 ${ }^{* *}$ ・沢 俊行 ${ }^{* *}$ ・岩本 剛 ${ }^{* *}$
}

\begin{abstract}
要旨
本研究は静的曲げモーメントを受ける同種材料段付き重ね合わせ接着継手，特に接着界面の応力分布を求 めるための三次元有限要素応力解析を行った。接着層の縦弹性係数, 接着層厚さ, 被着体段数が継手の強度 に及ぼす影響を調べた。接着層の縱弹性係数が大きいほど, 接着層厚さが小さいほど, 被着体段数が多いほ ぞ，継手の強度が向上することが分った。解析結果の妥当性を確かめるために，ひずみ測定実験及び三次元 有限要素解析を行い，本計算結果とひずみ测定実験結果を比較し両者はかなりよく一致した。実際に継手の 破壊試験を行い，三次元弾塑性計算による強度推定結果と比較し両者はかなりよく一致した。
\end{abstract}

\section{1. 緒 言}

近年接着接合は高分子化学の発展に伴い航空宇宙産業や 自動車産業等の機械構造物及び電子デバイス産業等かな り広範囲にわたって使用されるようになってきた1)。接着 継手には単純重稀わせ接着継手 ${ }^{2 \sim 5)}$, 単純突合せ接着継

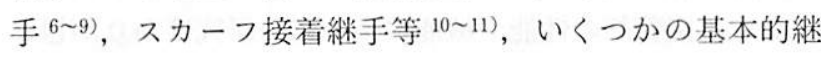
手形状があり，段付き重ね合わせ接着継手む基本的継手形 態のひとつである。従来の段付き重稀わせ接着継手に関 する研究 ${ }^{12 \sim 19)}$ はいくつか行われており, 森ら ${ }^{14 ~ 16) ~}$ は有限 要素法を用いて接着接合部のアスペクト比及び被着体段数 が接着剤の応力分布に及ぼす影響を調へ，継手の強度予測 を行っている。Erdogan ら ${ }^{17)}$ は応力解析を行い, ステップ 端における応力を明らかにし，スカーフ接着継手及び単純 重ね合わせ接着継手との比較を行っている。Hart-Smith ら ${ }^{18)}$ 及び Cushman ら ${ }^{19)}$ は応力解析と強度評価を行って いる。しかしこれらの研究は引張荷重を受ける場合に限定 された場合や二次元解析に上るむのが多く, 引張り荷重 以外の荷重形態及び継手の厚み方向の端部に発生すると予 想される特異性を考慮した三次元解析による段付き重权合 わせ接着継手の研究は著者らによる引張り荷重を受ける場

\footnotetext{
* (懒) 日立製作所

茨城県ひたちなか市大字高場 2520 番地 テ312-8506 **広島大学大学院工学研究科

広島県東広島市鏡山 1-4-1 于 739-8527

（原稿受付日: 平成 19 年 7 月 9 日)
}

合 20$)$ を除いてなされていないようである。このため段付 き重叔合わせ接着継手の合理的設計法の確立においても引 張り荷重の他に曲げモーメント等の荷重形態を考慮した三 次元解析によるより詳細なデー夕の蓄積が必要である。な お曲げモーメントを受ける突合せ接着継手の二次元応力解 析 ${ }^{21)}$ は既になされている。

そこで本研究では同種材料段付き重㸚合わせ接着継手に 静的曲げモーメントが作用する場合の接着層の縦弹性係数, 接着層厚さ及び被着体段数が接着層内の応力分布に及ぼす 影響を, 特に接着界面端部の応力分布に及ぼす影響を三次 元有限要素応力解析により明らかにする。また, 接着層内 のひずみ測定実験を行い, 本解析の妥当性を検討する。さ らに三次元弹塑性計算による継手の破壊時曲げモーメント の大きさの推定を行い, 実際の継手破壊試験結果と比較を 行う。

\section{2. 三次元有限要素解析方法}

Fig. 1 は有限要素解析（有限要素コード: ANSYS）に 用いた解析モデルを示す。段付き重ね合わせ接着継手は (1) 突合せ部 (butted sections) 上 (2) 重ね合わせ部 (lapped sections）から構成されている。本研究では突合せ部の数 を継手の段数 $\mathrm{N}$ とする。Fig. 1 中に示すように原点を 0 とし, 座標軸は継手の幅方向を $\mathrm{x}$, 長手方向を $\mathrm{y}$, 厚さ方 向を $\mathrm{z}$ 軸方向とする直交座標系 $(x, y, z)$ を用いる。静的 曲げモーメントを受ける段付き重㸚合わせ接着継手におい て, 荷重を作用させる側の被着体を荷重作用側被着体, 拘 


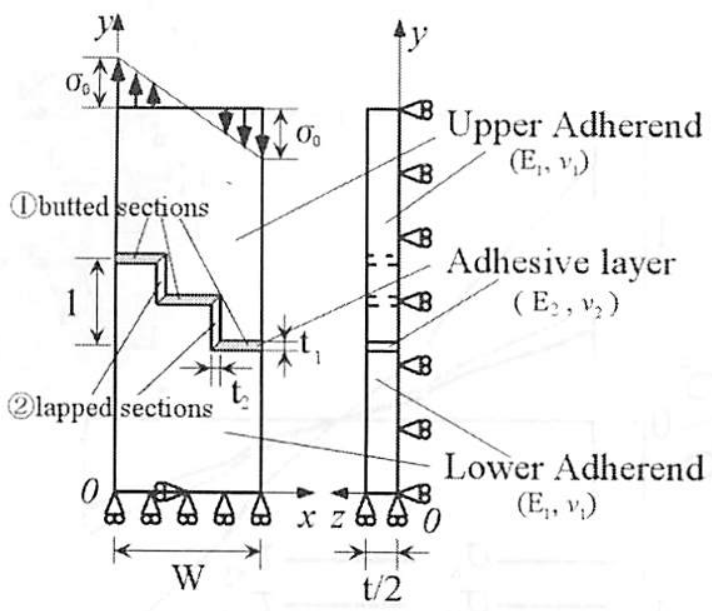

Fig. 1 A model for 3-D FEM calculations (the case of $\mathrm{N}=3$ )

束される側の被着体を拘束側被着体と呼ぶこととする。同 様に荷重作用側被着体と接着層との界面を荷重作用側接着 界面, 拘束側被着体と接着層との界面を拘束側接着界面之 呼ぶ。接着される二つの被着体は同一材料, 寸法とし, 被 着体の縦弾性係数及びポアソン比をそれぞれ $\mathrm{E}_{1}$ 及び $\nu_{1}$ 上 する。また，接着層のそれらを $\mathrm{E}_{2}, \nu_{2}$ とする。乫合せ部接 着層厚さを $\mathrm{t}_{1}$, 重的合わせ部接着層厚さを $\mathrm{t}_{2}$, 継手厚さ を $\mathrm{t}$ とする。有限要素解析は継手の厚さ方向 ( $\mathrm{z}$ 軸方向) の対称性を考慮して $1 / 2$ 部分を解析対象とする。

有限要素解析に用いた境界条件は継手の拘束側被着体の 端面を $\mathrm{y}$ 方向に拘束, 及び端面中央を $\mathrm{x}$ 軸方向に拘束し, 荷重作用側端面に線形分布の応力 $\sigma_{\mathrm{y}}$ (最大曲げ応力 : $\sigma_{0}$ ) を作用させることにより，継手に曲げモーメント M を与 える。Table 1 は本計算で用いた被着体及び接着剤の材料 定数を示す。解析に用いた材料定数は実験に用いたそれら と対応させた。被着体の材質は軟鋼 SS400 (JIS) を，接 着剂は常温硬化型エポキシ系構造用接着剤（住友 $3 \mathrm{M}$ 製 Scotch-Weld 1838）を想定している。

Fig. 2 は解析モデルの要素分割の一例を示す。寸法は後 に行う実験における試験片寸法（Fig. 3）に対応させ, 段数 $N=3$ としている。総要素数, 総節点数はそれぞれ 113280 及び 126973 である。また, 特異応力の発生が予想 される位置付近での最小要素寸法は $5 \mu \mathrm{m}$ としている。

Table 1 The material properties for the adherends and the adhesive used in this study

\begin{tabular}{c|c|c}
\cline { 2 - 3 } & $\begin{array}{c}\text { Adherend } \\
\text { SS400 }\end{array}$ & $\begin{array}{c}\text { Adhesive } \\
\text { Scotch-weld } 1838\end{array}$ \\
\hline $\begin{array}{c}\text { Young's } \\
\text { modulus } \\
\text { E (GPa) }\end{array}$ & 209 & 3.34 \\
\hline $\begin{array}{c}\text { Poisson's ratio } \\
\nu\end{array}$ & 0.29 & 0.38 \\
\hline
\end{tabular}

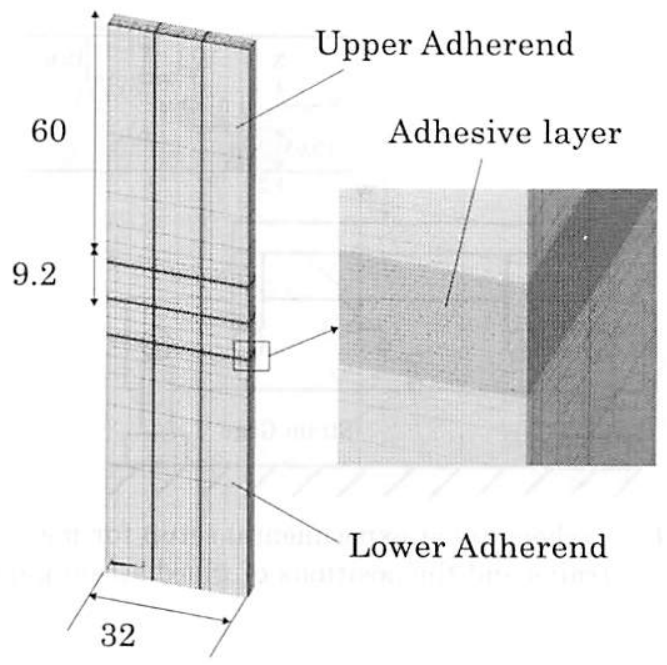

Fig. 2 Example of mesh divisions in FEM calculations $\left(\mathrm{N}=3, \mathrm{t}_{1}=\mathrm{t}_{2}=0.1\right)$

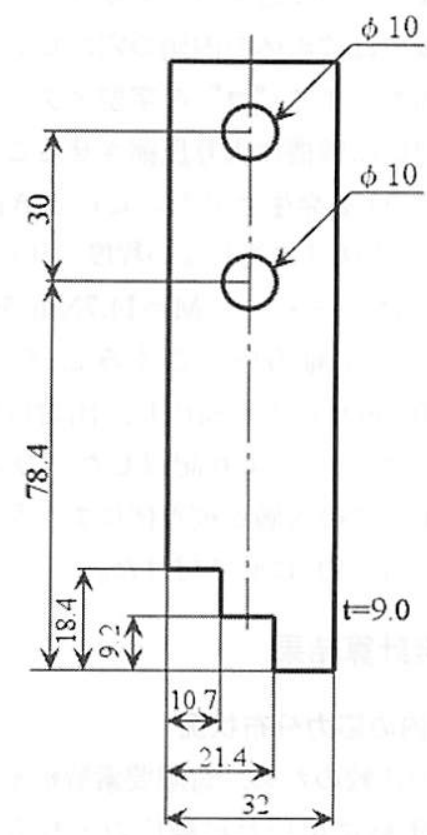

Fig. 3 The dimensions and shapes of adherend the specimens

\section{3. 実験方法}

有限要素解析結果との比較のため, 静的曲げモーメン トを受ける同種材料段付き重ね合わせ接着継手のひずみ 測定実験を行う。Fig. 3 は本実験で用いた試験片の形状 及び寸法を示す。被着体の材質は構造用鋼 SS400 (JIS) で, 厚さ $\mathrm{t}=9.0 \mathrm{~mm}$ である。接着は接着面をブタノン $\left(\mathrm{C}_{2} \mathrm{H}_{8} \mathrm{COCH}_{3}\right)$ を用いて脱脂, 洗浄し, 常温硬化型エポキ

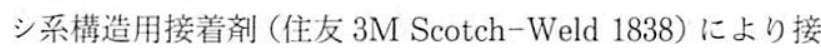
着した。常温で 24 時間放置し硬化させ, 電気炉中で $65^{\circ} \mathrm{C}$ で 2 時間加熱しキュアリングを行った。突合せ部接着層厚 さ及び重ね合わせ部接着層厚さは治具を用いて調整し， $\mathrm{t}_{1}=$ $\mathrm{t}_{2}=0.1 \mathrm{~mm}$ とした。また被着体はワイヤーカットで製作 


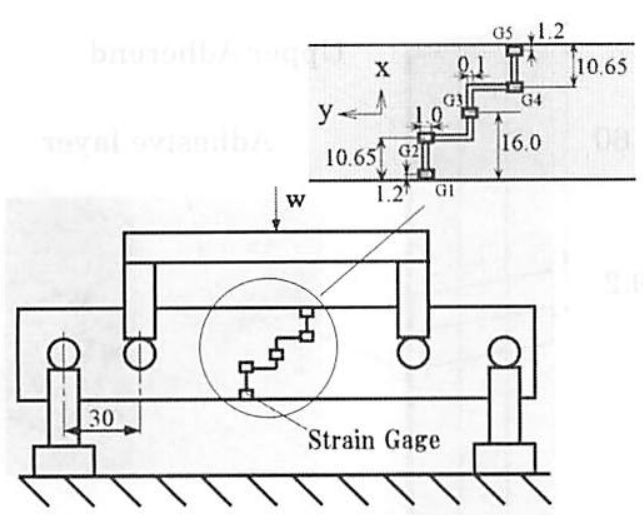

Fig. 4 A schematic of experimental setup for measuring strains and the positions of glued strain gages

$し$, 接着面の中心線平均表面粗さは $\mathrm{R}_{\mathrm{a}}=0.4 \mu \mathrm{m}$ 程度であ る。

Fig. 4 は実験装置の概略及びひずみゲージの貼り付け位. 置を示す。実験では被着体の内側の穴にピンを差し込み, これにガイド棒を有する“コ”の字型アタッチメントをピ ン上に載せ, 材料試験機により圧縮させることにより四点 曲げモーメント M を発生させた。このとき曲げモーメン トM は接着剤が降伏域に達しない程度の圧縮力 $\mathrm{W}=980 \mathrm{~N}$ を作用させ, 曲げモーメント $\mathrm{M}=14.7 \mathrm{Nm}$ を発生させた。 継手の長手方向（y 軸方向）ひずみ $\varepsilon_{\mathrm{y}}$ をひずみゲージ （ゲージ長：1.0mm）により検出し, 出力は動ひずみ計を 介してオシロスコープにより記録した。ひずみゲージは Fig. 4 に示すように接着層と被着体にまたがるように継手 の両面 $(z / t= \pm 1 / 2)$ に貼り付けた。

\section{4. 有限要素計算結果}

\section{1 接着層内の応力分布状況}

実験結果との比較のため, 有限要素解析モデルの寸法及 び材料定数は実験に用いた試験片のそれら（Fig. 3 及び

Table 1) と対応させた。

Fig. 5 は継手の厚さ方向表面 $(\mathrm{z} / \mathrm{t}=1 / 2)$ かつ荷重作用 側被着体突合せ部接着界面 (Fig. 5 中の点 $a-b, c-d, e-f$ ) における $\mathrm{N}=3$ の場合の各応力成分の分布状況を示す。縦 軸には $\sigma_{\mathrm{x}}, \sigma_{\mathrm{y}}, \sigma_{z}, \tau_{\mathrm{xy}}, \tau_{\mathrm{yz}}$ 及び $\tau_{\mathrm{zx}}$ の各応力成分の值を最大 曲げ応力 $\sigma_{0}$ (Fig. 1) で無次元化した值を, 横軸には $\mathrm{x}$ 軸 方向の位置 $\mathrm{x}$ を試験片の幅 $\mathrm{w}$ で無次元化した值 $\mathrm{x} / \mathrm{w}$ を示 す。これより笑合せ部接着界面においては $\mathrm{y}$ 軸方向垂直 応力 $\sigma_{y}$ が最も大きな值をとり, 継手の破壊に対して最も 支配的であると考えられる。

Fig. 6 は継手の厚さ方向の表面 $(\mathrm{z} / \mathrm{t}=1 / 2)$ かつ重ね合 わせ部接着界面 (点 $g-h, i-j$ ) における各応力成分の分 布状況を示し，縦軸はFig. 5 と同じである。横軸にはy 軸方向の位置 $\mathrm{y}$ を重放合わせ部の長さ 1 で無次元化した值 $\mathrm{y} / 1$ を示す。これより, 重ね合わせ部接着界面端部（点 $\mathrm{g}$ )

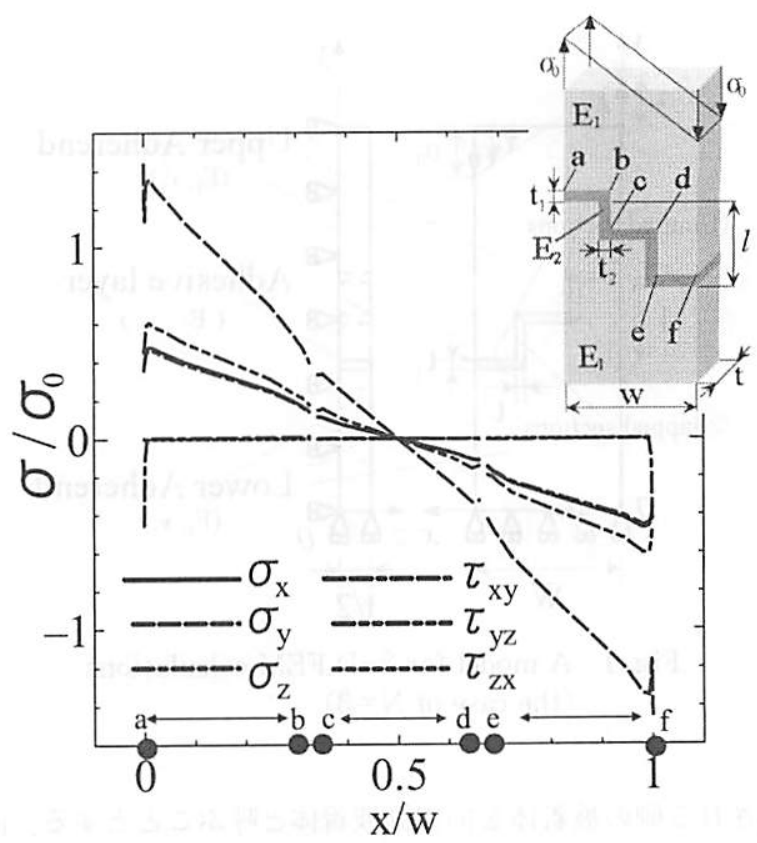

Fig. 5 Distributions of the stress components at the butted interfaces $(\mathrm{z} / \mathrm{t}=1 / 2, \mathrm{~N}=3)$

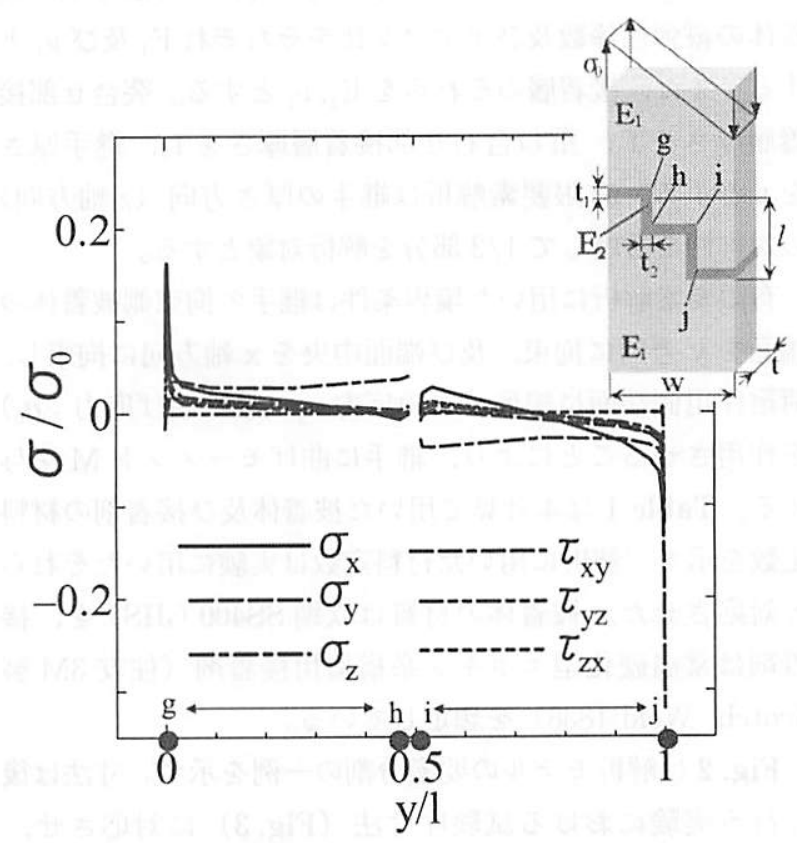

Fig. 6 Distributions of the stress components at the lapped interfaces $(\mathrm{z} / \mathrm{t}=1 / 2, \mathrm{~N}=3)$

において $\mathrm{y}$ 軸方向垂直応力 $\sigma_{\mathrm{y}}$ が最む大きな值となる。こ の結果と Fig. 5 の結果との比較より, 乫合せ部における 応力成分 $\sigma_{y} / \sigma_{0}$ の最大值が重稀合わせ部における応力成分 $\sigma_{\mathrm{y}} / \sigma_{0}$ の最大值よりかなり大きいことが示されている。し たがって継手の破壊は突合せ部より起こると考えられる。

Fig. 7 は突合せ部 $(\mathrm{z} / \mathrm{t}=1 / 2)$ における接着層内の無次 元化された最大主応力 $\sigma_{1} / \sigma_{0}$ 及び無次元化されたミーゼス 相当応力 $\sigma_{\mathrm{m}} / \sigma_{0}$ の応力分布を示す。接着層内の応力分布之 して荷重作用側接着界面 (interface I), 拘束側接着界面 


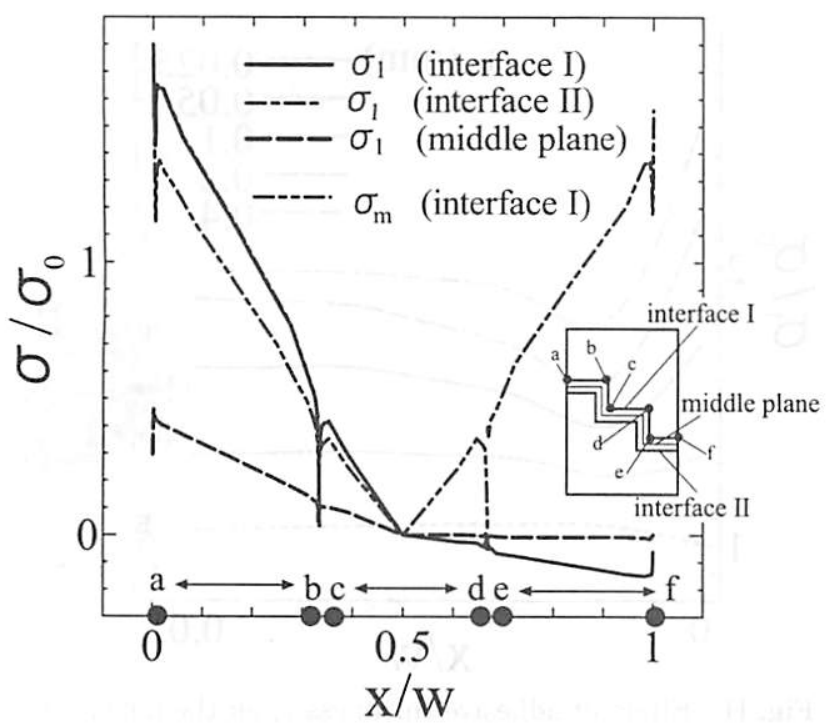

Fig. 7 Stress distributions $\sigma_{1}$ and $\sigma_{\mathrm{m}}$ in the adhesive $(\mathrm{z} / \mathrm{t}=1 / 2, \mathrm{~N}=3)$

(interface II), 及び接着層中央部 (middle plane) におけ る最大主応力分布状況, 荷重作用側接着界面 (interface I) におけるミーゼス相当応力分布状況を示す。これより, 突 合せ部接着層内においては接着界面における応力值が接着 層中央部における応力值よりあ大きいことが示されている。 また, 最大主応力及びミーゼス相当応力は乫合せ部接着界 面端部（点 $\mathrm{a}, \mathrm{x}=0, \mathrm{y}=123.6, \mathrm{z} / \mathrm{t}=1 / 2$ ) において最大 の值を示し, 最大主応力の最大值はミーゼス相当応力の最 大值よりあ大きいことが示されている。したがって以降, 継手の破壊が起こると考えられる突合せ部接着界面端部 (点 $\mathrm{a}, \mathrm{x}=0, \mathrm{y}=123.6, \mathrm{z} / \mathrm{t}=1 / 2$ ) における最大主応力分 布の比較榆討を行う。

\subsection{2 次元解析結果と 3 次元解析結果の比較}

Fig. 8 は荷重作用側接着界面における無次元化された最 大主応力 $\sigma_{1}$ の分布を 2 次元解析（平面ひずみ）の場合と 3 次元解析の場合の比較を示す。縦軸は無次元化した最大 主応力 $\sigma_{1} / \sigma_{0}$ を, 横軸は $\mathrm{x}$ 軸方向の位置 $\mathrm{x}$ を継手の寸法 $\mathrm{w}$ で無次元化した值 $\mathrm{x} / \mathrm{w}$ を示す。Fig. 9 は試験片厚さ方向 ( $\mathrm{z}$ 方向) の荷重作用側接着界面端部 (点 $\mathrm{a}, \mathrm{x}=0, \mathrm{y}=123.6$ ) における無次元化された最大主応力 $\sigma_{1} / \sigma_{0}$ の分布を示す。 横軸は $\mathrm{z}$ 軸方向の位置 $\mathrm{z}$ を試験片厚さ $\mathrm{t}$ で無次元化した值 $\mathrm{z} / \mathrm{t}$ を示す。 2 次元解析においては, 突合せ部接着層厚さ $\mathrm{t}_{1}$ が試験片厚さ $\mathrm{t}$ と比較して十分小さいと考えて平面ひず み状態として計算を行う。最小要素寸法は 3 次元解析と同 様に $5 \mu \mathrm{m}$ としている。

Fig. 8 より平面ひずみ状態において 2 次元解析結果と 3 次元解析結果により求められた継手の厚さ方向中央部にお ける最大主応力分布の差はかなり小さいと思われる。しか L Fig. 9 より試験片厚さ方向表面 $(\mathrm{z} / \mathrm{t}=1 / 2)$ の特異性 により無次元化された最大主応力 $\sigma_{1} / \sigma_{0}$ が最大になること

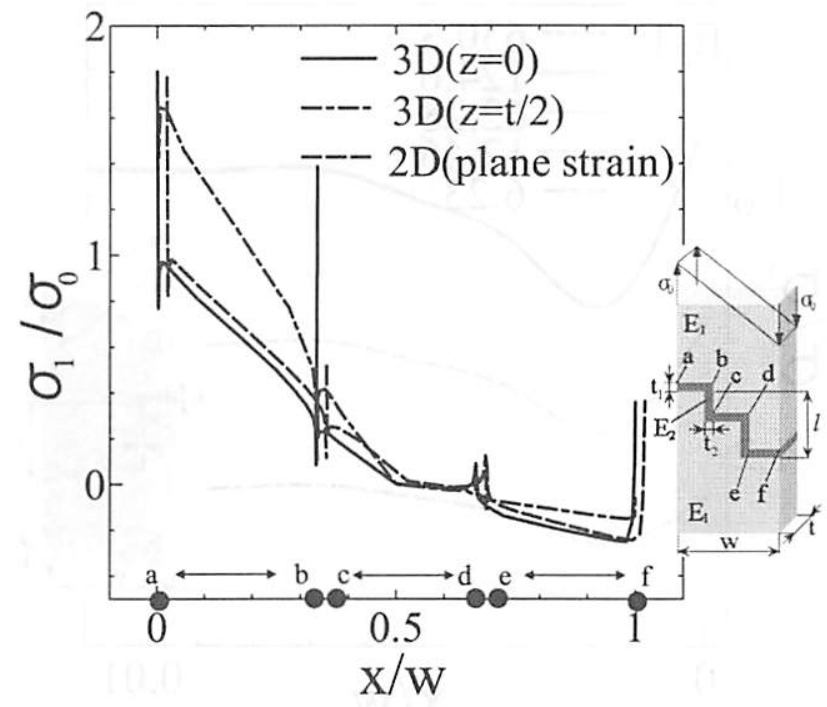

Fig. 8 Comparison of distributions between 2-D and $3-D$ calculations $(z / t=1 / 2, N=3)$

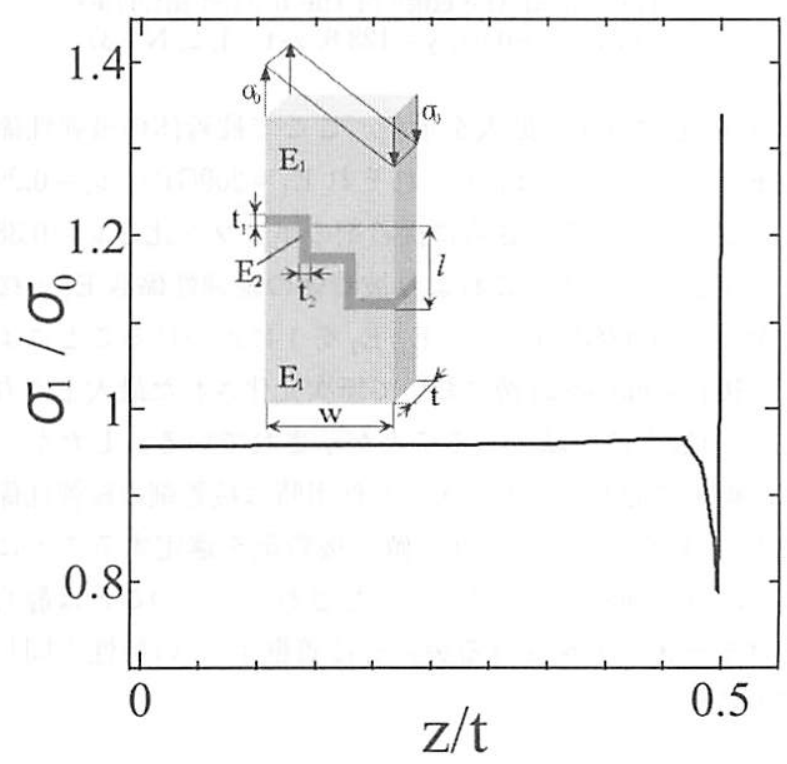

Fig. 9 The distribution of maximum principle stress in the $\mathrm{z}$-direction $(\mathrm{x} / \mathrm{w}=0, \mathrm{y}=123.6, \mathrm{~N}=3)$

が示されており，Fig. 8 においても継手の厚さ方向表面 $(\mathrm{z} / \mathrm{t}=1 / 2)$ において最大主応力分布は最大となっている。 2 次元解析結果は継手の厚さ方向の特異性が考慮された 3 次元解析結果よりも小さい応力值を示すため, 機械構造物 の安全性を考虑した設計のためのデータとしては危険であ ると推測される。以上のことを考虑して, 以降の応力解析 及び強度推定は継手の厚さ方向表面の荷重作用側接着界面 端部（点 $a, x=0, y=123.6, z / t=1 / 2$ ) の荷重作用側接 着界面の最大主応力分布について行う。

\section{3 接着剤の縦弾性係数 $\mathrm{E}_{2}$ の影響}

Fig. 10 は接着剤の縦弾性係数 $\mathrm{E}_{2}$ を変化させたときの突 合せ部荷重作用側接着界面端部近傍（点 $\mathrm{a}, \mathrm{x} / \mathrm{w}=0 \sim 0.01$, $\mathrm{y}=123.6, \mathrm{z} / \mathrm{t}=1 / 2)$ における無次元化された最大主応力 


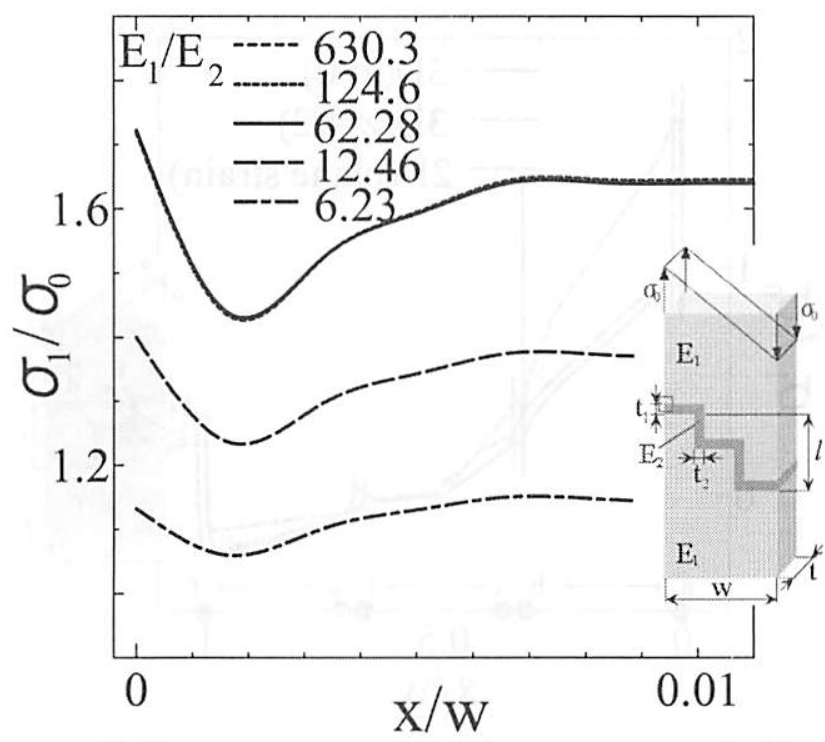

Fig. 10 Effect of adhesive Young's modulus $\mathrm{E}_{2}$ on the normalized maximum principle stress distributions near the edge of the butted interface $(\mathrm{x} / \mathrm{w}=0 \sim 0.01, \mathrm{y}=123.6, \mathrm{z} / \mathrm{t}=1 / 2, \mathrm{~N}=3)$

$\sigma_{1} / \sigma_{0}$ の応力分布の拡大を示す。ここで被着体の縱弾性係 数 $\mathrm{E}_{1}$, ポアソン比 $\nu_{1}$ をそれぞれ $\mathrm{E}_{1}=209 \mathrm{GPa}, \nu_{1}=0.29$ と一定としている。さらに接着剤のポアンン比を $\nu_{2}=0.38$ で一定としている。これより被着体の縦弹性係数 $\mathrm{E}_{1}$ 上接 着剤の縦弾性係数 $\mathrm{E}_{2}$ の比 $\mathrm{E}_{1} / \mathrm{E}_{2}$ を 1 に近づけることによ り，接着界面端部近傍において無次元化された最大主応力 $\sigma_{1} / \sigma_{0}$ の最大值が減少することが示されている。したがっ て, 継手に静的曲げモーメント作用時は接着剂の縦弾性係 数 $\mathrm{E}_{2}$ の值が $\mathrm{E}_{1}$ により近い値の接着剤を選定することに より, 継手強度が向上すると予想される。このことは静的 曲げモーメントを受ける乫合せ接着継手 ${ }^{21)}$ の特性と同じ である。

\section{4 突合せ部接着層厚さ $\mathrm{t}_{1}$ の影響}

Fig. 11 は突合せ部接着層厚さ $\mathrm{t}_{1}$ が突合せ部荷重作用側 接着界面端部近傍（点 $\mathrm{a}, \mathrm{x} / \mathrm{w}=0 \sim 0.01, \mathrm{y}=123.6, \mathrm{z} / \mathrm{t}=$ $1 / 2$ ）における無次元化された最大主応力 $\sigma_{1} / \sigma_{0}$ の応力分 布に及ぼす影響を示す。ここで被着体の縦弹性係数 $\mathrm{E}_{1}$, ポアソン比 $\nu_{1}$ をそれぞれ $\mathrm{E}_{1}=209 \mathrm{GPa}, \nu_{1}=0.29$ と一定と している。また接着剤の縦弾性係数 $\mathrm{E}_{2}$ 及びポアンン比を $\mathrm{E}_{2}=3.34 \mathrm{GPa}, \nu_{2}=0.38$ で一定としている。これより, 哭 合せ部接着層厚さ $\mathrm{t}_{1}$ を小さくすることにより, 接着界面 端部近傍において無次元化された最大主応力 $\sigma_{1} / \sigma_{0}$ の最大 值が減少することが示されている。したがって, 継手に静 的曲げモーメント作用時には笑合せ部接着層厚さ $\mathrm{t}_{1}$ を小 さくすることにより継手強度が向上すると予想さ机る。こ のことは引張り荷重を受ける段付き重ね合わせ接着継手 20) 及び静的曲げモーメントを受ける突合せ接着継手 21) の特 性と同じである。

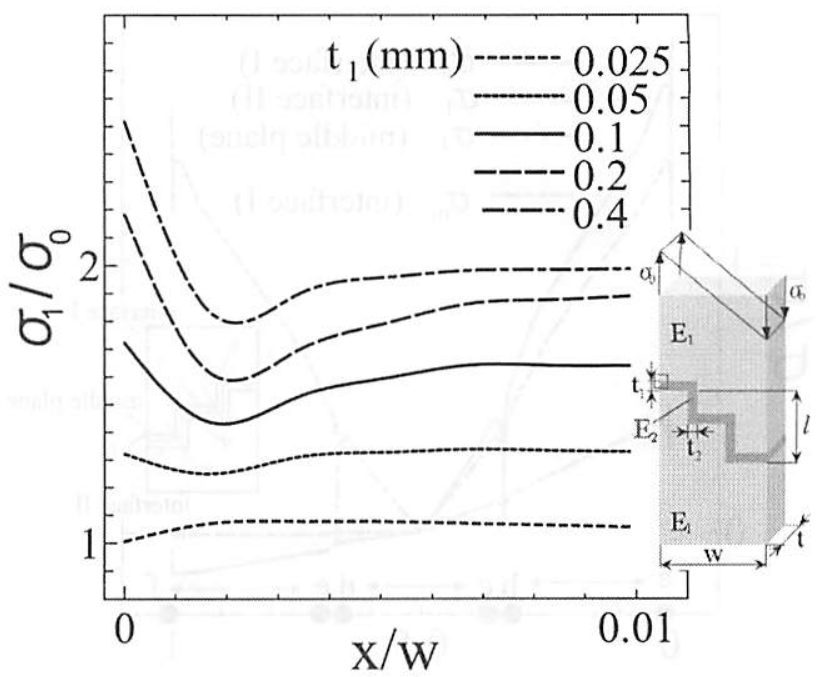

Fig. 11 Effect of adhesive thickness $t_{1}$ on the normalized maximum principle stress distribution near the edge of the butted interface $(\mathrm{x} / \mathrm{w}=0 \sim 0.01, \mathrm{y}=$ 123.6, $\mathrm{z} / \mathrm{t}=1 / 2, \mathrm{~N}=3$ )

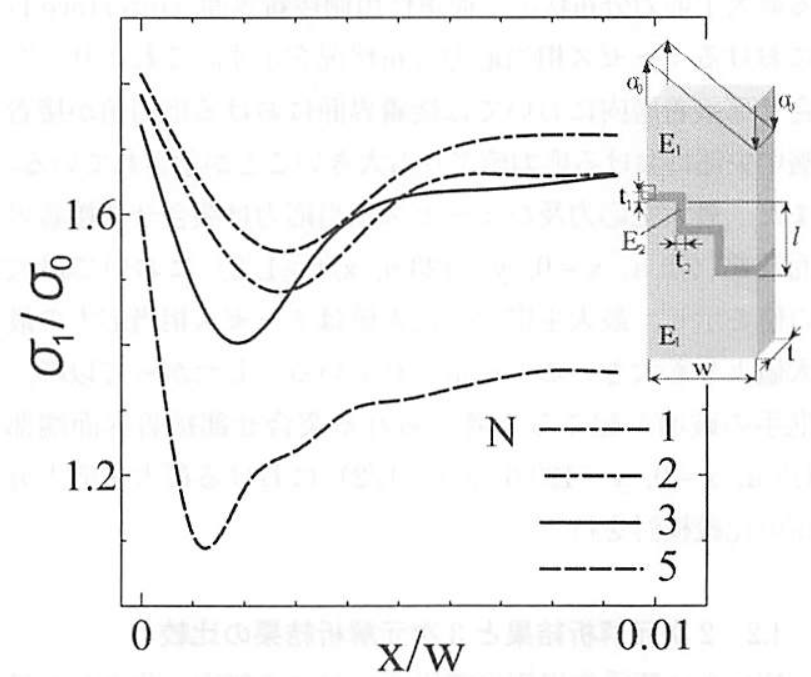

Fig. 12 Effect of the number of steps on the normalized maximum principle stress distribution near the edge of butted interface $(\mathrm{x} / \mathrm{w}=0 \sim 0.01, \mathrm{y}=123.6$, $\mathrm{z} / \mathrm{t}=1 / 2, \mathrm{~N}=3$ )

\section{5 被着体段数 $\mathrm{N}$ の影響}

Fig. 12 は被着体段数 $\mathrm{N}$ が突合せ部荷重作用側接着界面 端部近傍（点 $\mathrm{a}, \mathrm{x} / \mathrm{w}=0 \sim 0.01, \mathrm{y}=123.6, \mathrm{z} / \mathrm{t}=1 / 2$ ) に おける無次元化された最大主応力 $\sigma_{1} / \sigma_{0}$ の応力分布に及ぼ す影響を示す。ここで被着体の縦弾性係数 $\mathrm{E}_{1}$, ポアソン 比泣をそれぞれ $\mathrm{E}_{1}=209 \mathrm{GPa}, \nu_{1}=0.29$ と一定とする。ま た接着剤の縦弾性係数 $\mathrm{E}_{2}$ 及びポアソン比を $\mathrm{E}_{2}=3.34 \mathrm{GPa}$, $\nu_{2}=0.38$ で一定とする。なお継手の全長は一定, すなわち 重敉合わせ部の面積は一定とする。被着体段数 $\mathrm{N}$ を 1,2 , 3 及び 5 としている。これより被着体段数 $\mathrm{N}$ を多くする ことにより接着界面端部近傍において無次元化された最大 主応力 $\sigma_{1} / \sigma_{0}$ の最大值が減少することが示されている。し 
たがって，継手に静的曲げモーメント作用時には被着体段 数 $\mathrm{N}$ を多くすることにより継手強度が向上すると予想さ れる。この特性は引張り荷重を受ける段付き重ね合わせ接 着継手 20 22) と同一である。

\section{5. 実験結果と有限要素計算結果の比較}

\section{1 接着層内のひずみ測定実験}

Fig. 13 は乫合せ部接着界面近傍 $(\mathrm{z} / \mathrm{t}=1 / 2)$ における ひずみ測定試験結果と, 有限要素計算結果の比較を示す。 縦軸には継手の長手方向である $\mathrm{y}$ 軸方向のひずみ $\varepsilon_{\mathrm{y}}$ を, 横軸には $\mathrm{x}$ 軸方向の位置 $\mathrm{x}$ を継手の寸法 $\mathrm{w}$ で無次元化し た值 $\mathrm{x} / \mathrm{w}$ を示す。ひずみゲージは上部接着界面，下部接 着界面及び接着層にわたって貼り付けた。また，実験にお いて計測したひずみの值はひずみゲージを貼り付けた部分 のひずみの平均值として出力されるため, 有限要素計算に おいてもひずみゲージの貼り付け位置と対応する位置にあ る要素のガウス点での $\mathrm{y}$ 方向ひずみ $\varepsilon_{\mathrm{y}}$ を平均した值をひ ずみ $\varepsilon_{\mathrm{y}}$ とした。なお一例として Fig. 4 中に示すひずみゲー ジ G1の貼り付け位置に対応する位置にある要素のガウス 点での $\mathrm{y}$ 方向ひずみ $\varepsilon_{\mathrm{y}}$ を求めた。接着層（厚さ $0.1 \mathrm{~mm}$ ) の要素 20 点のひずみ $\varepsilon_{\mathrm{y}}$ の平均值が $1300 \times 10^{-6}$ となり, 被着体 $(0.9 \mathrm{~mm})$ 部分の要素 14 点のひずみ $\varepsilon_{y}$ の平均值が $45.6 \times 10^{-6}$ となった。したがってゲージ長さ $1 \mathrm{~mm}$ 内の要 素数 34 点のひずみの平均值は $\varepsilon_{\mathrm{y}}=170 \times 10^{-6}$ となり, 测 定值 $\varepsilon_{y}=180 \times 10^{-6}$ とかなりよく一致する結果が得られた。 これより,ひずみ測定試験結果と有限要素計算結果はかな り良く一致することが示されている。

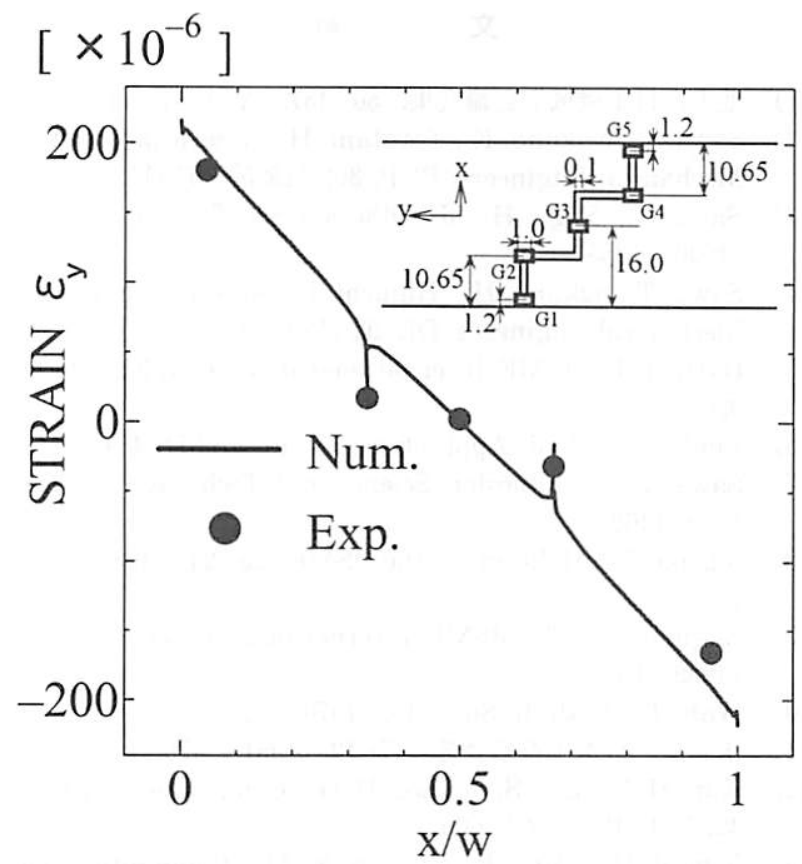

Fig. 13 Comparisons of the strains between the calculated and the experimental results

\section{2 継手破壊試験}

Fig. 14 は実験より得られた接着剤（住友 $3 \mathrm{M}$ 製 Scotch -Weld 1838）の応力ーひずみ線図を示す。継手の強度推 定はこの応力ーひずみ線図を用いて三次元弾塑性有限要素 計算により行う。有限要素解析においては, 接着剤の応力ひずみ線図を二直線近似（破線）し，接着界面端部（点 $\mathrm{a}$, $\mathrm{x} / \mathrm{w}=0, \mathrm{y}=123.6, \mathrm{z} / \mathrm{t}=1 / 2)$ に作用する最大主応力が接 着剤の破壊応力 $50.96 \mathrm{MPa}$ に達したときに継手の破壊が 生じると考えた。また継手の破壊時曲げモーメント $\mathrm{M}_{\mathrm{r}}$ は 最小要素寸法に依存すると考えられるため, 最小要素寸法 を $\mathrm{x}, \mathrm{y}, \mathrm{z}$ の全方向に関して $10 \mu \mathrm{m}$ 及び $5 \mu \mathrm{m}$ に变化さ せて破壊時曲げモーメント $\mathrm{M}_{\mathrm{r}}$ の推定を行った。

Fig. 15 は最小要素寸法が $5 \mu \mathrm{m}$ の上きの三次元弾塑性 有限要素計算により得られた突合せ部上部接着界面端部近 傍（点 $\mathrm{a}, \mathrm{x} / \mathrm{w}=0 \sim 0.01, \mathrm{y}=123.6, \mathrm{z} / \mathrm{t}=1 / 2$ ）における

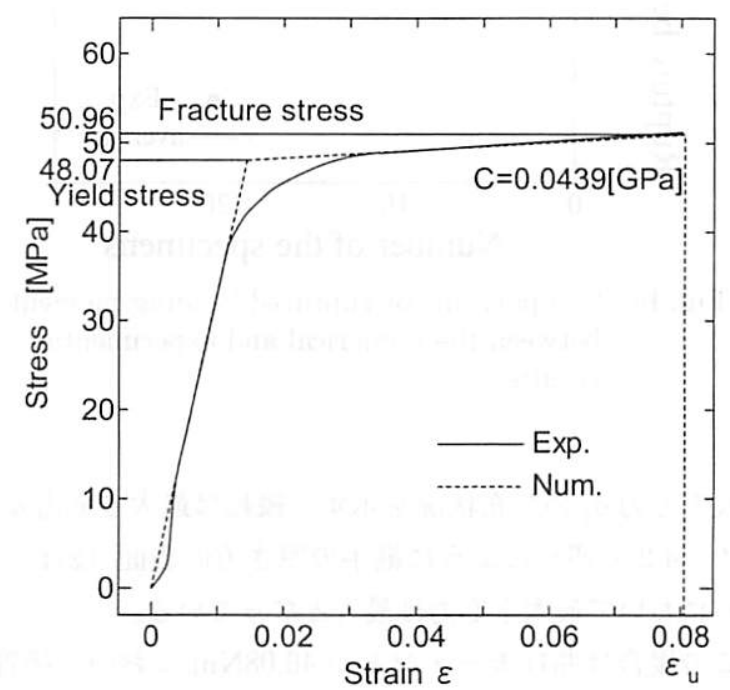

Fig. 14 The measured stress - strain curve (solid line) of the adhesive and the approximated stress-strain curve (dotted line) used in FEM calculations

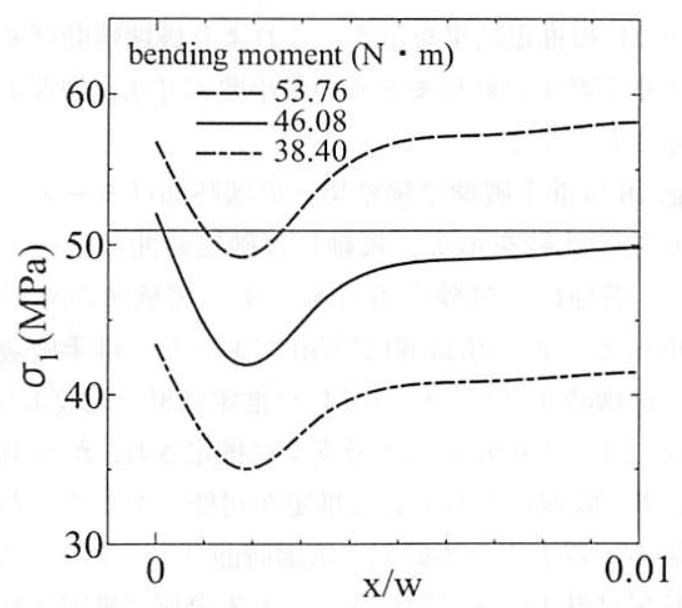

Fig. 15 Distributions of maximum principle stress at the edge of the interface calculated in elasto-plastic deformation ranges 
Table 2 The effect of the mesh size on the bending moment $\mathrm{Mr}$ when the joints ruptured obtained using 3-D FEM in elasto-plastic deformation range

\begin{tabular}{c|c}
\hline $\begin{array}{c}\text { Minimum mesh } \\
\text { size }(\mu \mathrm{m})\end{array}$ & $\begin{array}{c}\text { Ruptured bending } \\
\text { moment } \mathrm{M}_{\mathrm{r}}(\mathrm{N} \cdot \mathrm{m})\end{array}$ \\
\hline 5.0 & 46.08 \\
\hline 10.0 & 59.14 \\
\hline
\end{tabular}

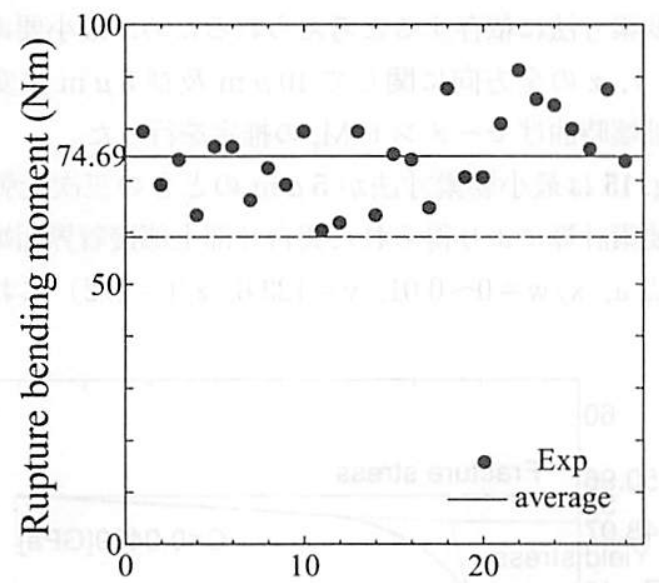

Number of the specimens

Fig. 16 Comparisons of ruptured bending moment between the numerical and experimental results

最大主応力 $\sigma_{1}$ の分布状況を示す。綎軸は最大主応力 $\sigma_{1}$ を 示す。 4.2 で述べたように継手の厚さ方向表面 $(\mathrm{z} / \mathrm{t}= \pm 1$ /2）において最大主応力は最大となっている。

この場合は曲げモーメントが $46.08 \mathrm{Nm}$ において接着界 面端部の最大主応力が $50.96 \mathrm{MPa}$ に達している。このと きの破壊時曲げモーメントは $\mathrm{M}_{\mathrm{r}}=46.08 \mathrm{Nm}$ となった。

Table 2 は三次元弾塑性計算により得られた静的曲げモー メントを受ける段付き重ね合わせ接着継手の破壊時曲げモー メント $\mathrm{M}_{\mathrm{r}}$ の推定結果を示す。これより破壊時曲げモーメ ントの推定結果は解析モデルの最小要素寸法に依存するこ とが示されている。

Fig. 16 は継手破壊試験結果之破壊時曲げモーメントの 推定結果の比較を示す。縦軸には破壊時曲げモーメント $\mathrm{M}_{\mathrm{r}}$ を, 横軸には試験片番号を示す。実験値の平均値は $74.69 \mathrm{Nm}$ かっ最小値は $60.27 \mathrm{Nm}$ であった。継手破壊試験 結果と破壊時曲げモーメント $\mathrm{M}_{\mathrm{r}}$ の推定結果の比較より, 最 小要素寸法が $5 \mu \mathrm{m}$ では十分安全に推定され, かっ $10 \mu \mathrm{m}$ （Fig. 16 : 破線）であ十分に推定が可能であることが示さ れている。以上より本研究の破壊時曲げモーメント $\mathrm{M}_{\mathrm{r}}$ の 推定結果は継手破壊試験結果よりも安全側に推定されてい る。

\section{6. 結 言}

本研究では被着体が同種材料の段付き重稀わせ接着継 手に静的曲げモーメントが作用する場合の接着界面におけ る応力分布状況を有限要素コードANSYSにより三次元 有限要素解析を行い，また，接着層内のひずみ測定実験及 び継手破壊試験之計算結果の比較を行い，以下の結果が得 られた。

（1）静的曲げモーメントを受ける段付き重权合わせ接着継 手の突合せ部接着界面端部において, 最大主応力 $\sigma_{1}$ の値 が最大となった。

(2) 同種材料段付き重ね合わせ接着継手に静的曲げモーメ ント作用時には, (1) 被着体の緝弾性係数 $\mathrm{E}_{1}$ と接着剤の縦 弾性係数 $\mathrm{E}_{2}$ の比 $\mathrm{E}_{1} / \mathrm{E}_{2}$ を 1 に近づける, (2) 突合せ部接着 層厚さ $\mathrm{t}_{1}$ を小さくする, (3) 被着体段数 $\mathrm{N}$ を大きくするこ とにより接着界面における最大主応力 $\sigma_{1}$ の最大值が減少 することが分かった。なおこの特性は引張り荷重を受ける 段付き重权合わせ接着継手の特性と同一であることが分かっ た。

（3）三次元解析では継手の厚さ方向，特に表面の端面で特 異性が発生することを示し，二次元解析との差異を示した。 （4）本解析結果の妥当性を確かめるために行った接着層内 のひずみ測定試験結果と本解析結果はかなり良く一致した。 （5）三次元弹塑性有限要素計算により継手の破壊時曲げモー メントの推定を行い，継手破壊試験結果と比較したところ， 破壊時曲げモーメントの推定結果は要素寸法に依存するこ とが示され，実際の継手破壊試験結果よりも安全側に推定 された。

\section{文献}

1）池上，日本機械学会論文集，50-457，A（1984），1557。

2) Sawa. T., Nakano. K., Toratani. H., American Society of Mechanical Engineers, PVP, 302 (1995) 107-112.

3) Sawa. T., Suga, H., J. Adhesion Sci. Technol., 10-12, (1996), 1255.

4) Sawa. T., Okuno. H., Higuchi. I., American Society of Mechanical Engineers, DE, 92 (1996) 1-7.

5) Hattori. T., JSME International J. series 1, 34-3 (1991) $326-331$.

6) Lindsey G. H., J. Appl. phys., 38-12, (1967), 4843.

7) Sawa. T., J. Adhesion Science and Tech., 16-11 (2002) $1449-1468$.

8) Suzuki. Y., Bulletin of the JSME, 28-245 (1985) 25752584.

9) Sugibayashi. T., JSME International J. series $1,32-3$ (1989) $420-426$.

10) Wah. T., J. Mech. Soci., 18, (1976), 223.

11）永弘占，日本接着協会誌，17-12，(1981)，479.

12) Kim. H. S., Lee. S. J., Lee. D. G., Composite Structures, 32, 1-4 (1995) 593-600.

13) Kim. J. H., Park. B. J., Han. Y. M., Composite Structures, 66, 1-4 (2004) 69-75. 
14) Mori. K., Isono. H., Sugibayashi. T., JSME International J. series A, 39-3 (1996) 398-406.

15) Mori. K., Sugibayashi. T., JSME International J. series A, 33-3 (1990) 349-355.

16) Mori. K., Sugibayashi. T., J. Strain Analysis for Engineering Design, 27-3 (1992) 171-175.

17) Erdogan. F., Gupta. G. D., J. Applied Mechanics, DEC., 997 (1973).

18) Hart-Smith, L. J., NASA, CR-2218 (1974)
19) Cushman, J.B., McCleskey, S.F. and Ward, S. H., NASA, CR-3602 (1983).

20) Sawa. T., Ichikawa. K., American Society of Mechanical Engineers, DE 118 B(2), (2005), 819-825.

21) Sawa. T., Akita. Y., American Society of Mechanical Engineers, DE 118 B(2), (2005), 741-747.

22) Mori. K., Sugibayashi. T., Nippon Kikai Gakkai Ronbunshu, A 55 (517), (1989), 1966-1972.

\title{
$<$ Original Paper $>$
}

\section{Three-Dimensional Finite Element Analysis and Strength Estimation of Stepped-lap Adhesive Joints of Similar Adherends Subjected to Static Bending Moments}

\author{
Kohei ICHIKAWA*, Toshimasa NAGAI** Toshiyuki SAWA** and Takeshi IWAMOTO** \\ ${ }^{*}$ HITACHI Ltd \\ 2520, Takaba, Oji, Hitachinaka, Ibaragi, JAPAN \\ ** Graduate School of Engineering, University of Hiroshima \\ 1-4-1, Kagamiyama, Higashihiroshima, Hiroshima, 739-8527, JAPAN \\ (Accepted for publication : September 12, 2007)
}

\begin{abstract}
Stress distributions in stepped-lap adhesive joints of similar adherends subjected to static bending moment are analyzed in elastic deformation ranges using three-dimensional finite element method. The effect of the adhesive Young's modulus, the adhesive thickness and the number of steps of adherends on the stress distributions were examined under static bending moment. Using the interface stress distributions obtained from the FEM calculations, the joint strength is estimated. As the result, the maximum value of the maximum principle stress increased as the adhesive Young's modulus and the number of steps was decreased, while the adhesive thickness was increased. For verification of the FEM calculations, experiments to measure the strains of the stepped-lap adhesive joints were carried out using strain gauges. A fairly good agreement was found between the numerical and the measured results concerning the strains. The estimated bending moment when the joint was ruptured was in a fairly good agreement with the measured values.
\end{abstract}

Key words : Stepped-lap adhesive joint, Stress Analysis, finite element method, static bending moment, joint strength estimation

(Received : July 9, 2007) 